Article

\title{
Cancer Therapy by Catechins Involves Redox Cycling of Copper Ions and Generation of Reactive Oxygen Species
}

\author{
Mohd Farhan ${ }^{1}$, Husain Yar Khan ${ }^{2}$, Mohammad Oves ${ }^{3}$, Ahmed Al-Harrasi ${ }^{2}$, Nida Rehmani ${ }^{1}$, \\ Hussain Arif ${ }^{1}$, Sheikh Mumtaz Hadi ${ }^{1, *}$ and Aamir Ahmad ${ }^{4, *}$ \\ 1 Department of Biochemistry, Faculty of Life Sciences, AMU, Aligarh 202002, India; \\ farhan@mohdfarhan.com (M.F.); nida.rehmani4@gmail.com (N.R.); arifkap@gmail.com (H.A.) \\ 2 UoN Chair of Oman's Medicinal Plants and Marine Natural Products, University of Nizwa, Birkat Al Mauz, \\ PO Box 33, Postal Code 616, Nizwa, Oman; husainyar@gmail.com (H.Y.K.); \\ aharrasi@unizwa.edu.om (A.A.-H.) \\ 3 Center of Excellence in Environmental Studies, King Abdulaziz University, Jeddah 21589, Saudi Arabia; \\ owais.micro@gmail.com \\ 4 Karmanos Cancer Institute and Wayne State School of Medicine, Detroit, MI 48201, USA \\ * Correspondence: ahmada@karmanos.org (A.A.); smhadi1946@gmail.com (S.M.H.); \\ Tel.: +1-313-576-8315 (A.A.); +91-983-726-6761 (S.M.H.); Fax: +1-313-576-8389 (A.A.)
}

Academic Editor: Carmela Fimognari

Received: 2 January 2016; Accepted: 26 January 2016; Published: 4 February 2016

\begin{abstract}
Catechins, the dietary phytochemicals present in green tea and other beverages, are considered to be potent inducers of apoptosis and cytotoxicity to cancer cells. While it is believed that the antioxidant properties of catechins and related dietary agents may contribute to lowering the risk of cancer induction by impeding oxidative injury to DNA, these properties cannot account for apoptosis induction and chemotherapeutic observations. Catechin (C), epicatechin (EC), epigallocatechin (EGC) and epigallocatechin-3-gallate (EGCG) are the four major constituents of green tea. In this article, using human peripheral lymphocytes and comet assay, we show that $C$, EC, EGC and EGCG cause cellular DNA breakage and can alternatively switch to a prooxidant action in the presence of transition metals such as copper. The cellular DNA breakage was found to be significantly enhanced in the presence of copper ions. Catechins were found to be effective in providing protection against oxidative stress induced by tertbutylhydroperoxide, as measured by oxidative DNA breakage in lymphocytes. The prooxidant action of catechins involved production of hydroxyl radicals through redox recycling of copper ions. We also determined that catechins, particularly EGCG, inhibit proliferation of breast cancer cell line MDA-MB-231 leading to a prooxidant cell death. Since it is well established that tissue, cellular and serum copper levels are considerably elevated in various malignancies, cancer cells would be more subject to redox cycling between copper ions and catechins to generate reactive oxygen species (ROS) responsible for DNA breakage. Such a copper dependent prooxidant cytotoxic mechanism better explains the anticancer activity and preferential cytotoxicity of dietary phytochemicals against cancer cells.
\end{abstract}

Keywords: catechins; prooxidant; anticancer; copper; DNA breakage; reactive oxygen species; epicatechin; epigallocatechin; epigallocatechin-3-gallate

\section{Introduction}

In recent years, there has been an increasing interest in understanding the potential of cancer chemopreventive properties of plant derived polyphenolic compounds. Epidemiological evidence suggests that a high consumption of dietary products derived from plant sources among certain 
populations may reduce their risk of cancer induction as compared to those with low intakes [1-3]. This has been associated with human food stuff found to be rich in a wide variety of biologically active compounds [4]. Among such dietary constituents, catechins (a major component in green tea) are considered to be the most effective in cancer chemoprevention in humans. Catechins are a sub class of plant polyphenols that particularly include (+)-catechin (C), (-)-epicatechin (EC), (-)-epigallocatechin (EGC), and (-)-epigallocatechin-3-gallate (EGCG) and are considered as the most effective cytotoxic agents and inducers of apoptosis in cancer cells [5-8]. In recent years, several reports have documented that plant polyphenols including catechins induce apoptosis in various cell lines [9-13]. Of particular interest is the observation that a number of these polyphenols including catechins induce apoptotic cell death in various cell lines but not in normal cells $[5,10-12,14]$. However, the mechanism by which these compounds inhibit cell proliferation and induce apoptosis in cancer cells has been the subject of much interest. These compounds possess both antioxidant as well as prooxidant properties $[6,7,15]$. Evidence in the literature suggests that the antioxidant properties of such plant polyphenols may not fully account for their observed antiproliferative and cancer therapeutic effects [16]. We earlier proposed a hypothesis where we had explained that the prooxidant, rather than the antioxidant, activity of these compounds is important for their anticancer effects [17-19]. Such a prooxidant effect is induced in the presence of transition metals, such as copper. Copper is an important metal ion present in chromatin and is closely associated with DNA bases, particularly guanine [20]. It is one of the most redox active among the various metal ions present in biological systems facilitating rapid recycling, in the presence of molecular oxygen and compounds such as plant polyphenols, leading to the formation of reactive oxygen species (ROS) such as the hydroxyl radical.

In this article, we show that catechins can alternately behave as prooxidants in the presence of $\mathrm{Cu}$ (II) leading to cytotoxic action. Identification of molecular targets, modulation of which is associated with inhibition of malignantly transformed cells, is vital to cancer prevention and will greatly assist in a better understanding of anticancer mechanisms by naturally occurring chemotherapeutic compounds. A number of reports in the literature have established that tissue, serum, and cellular copper levels are considerably elevated in various malignancies [21-24]. Therefore, cancer cells may be more subject to electron transfer between copper ions and these catechins to generate ROS $[25,26]$. Such a mechanism, which involves a copper-dependent pathway of cell death, better explains the anticancer properties of polyphenols of diverse chemical structures, as also their preferential toxicity against cancer cells. The structures of various catechins used in this study are shown in Figure 1.

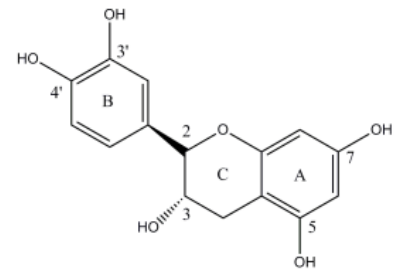

$(+)$-Catechin

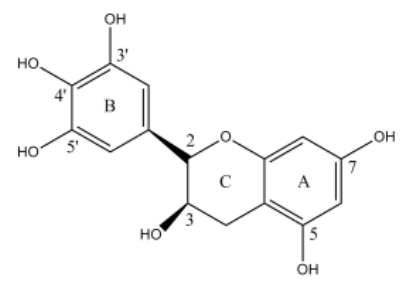

(-)-Epigallocatechin

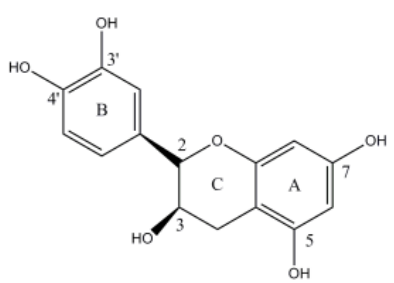

(-)-Epicatechin

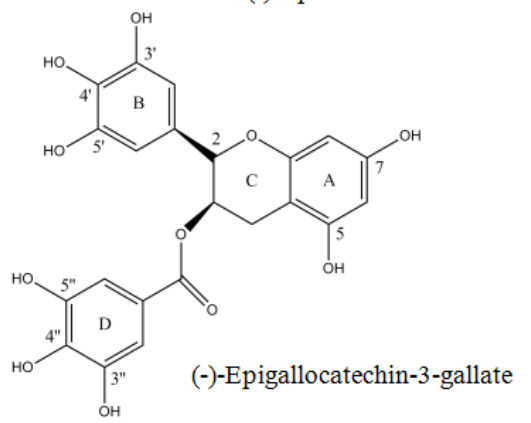

Figure 1. Chemical structure of catechin, epicatechin, epigallocatechin and epigallocatechin-3-gallate. 


\section{Results}

\subsection{Formation of Catechins-Cu(II) Complex}

The possibility for the formation of C/EC/EGC/EGCG with Cu(II) complex was examined. This was carried out by recording the absorption spectra of C, EC, EGC and EGCG with increasing concentrations of $\mathrm{Cu}(\mathrm{II})$. The results given in Figure 2 show that the addition of $\mathrm{Cu}(\mathrm{II})$ to $\mathrm{C}, \mathrm{EC}, \mathrm{EGC}$ and EGCG results in an enhancement in the peak appearing at their respective $\lambda_{\max }$. The absorption spectra of C, EC, EGC and EGCG in the presence of copper suggests a simple mode of interaction between these catechins and $\mathrm{Cu}(\mathrm{II})$. The absorption maxima of C, EC, EGC and EGCG lie in the range of 260-280 nm.

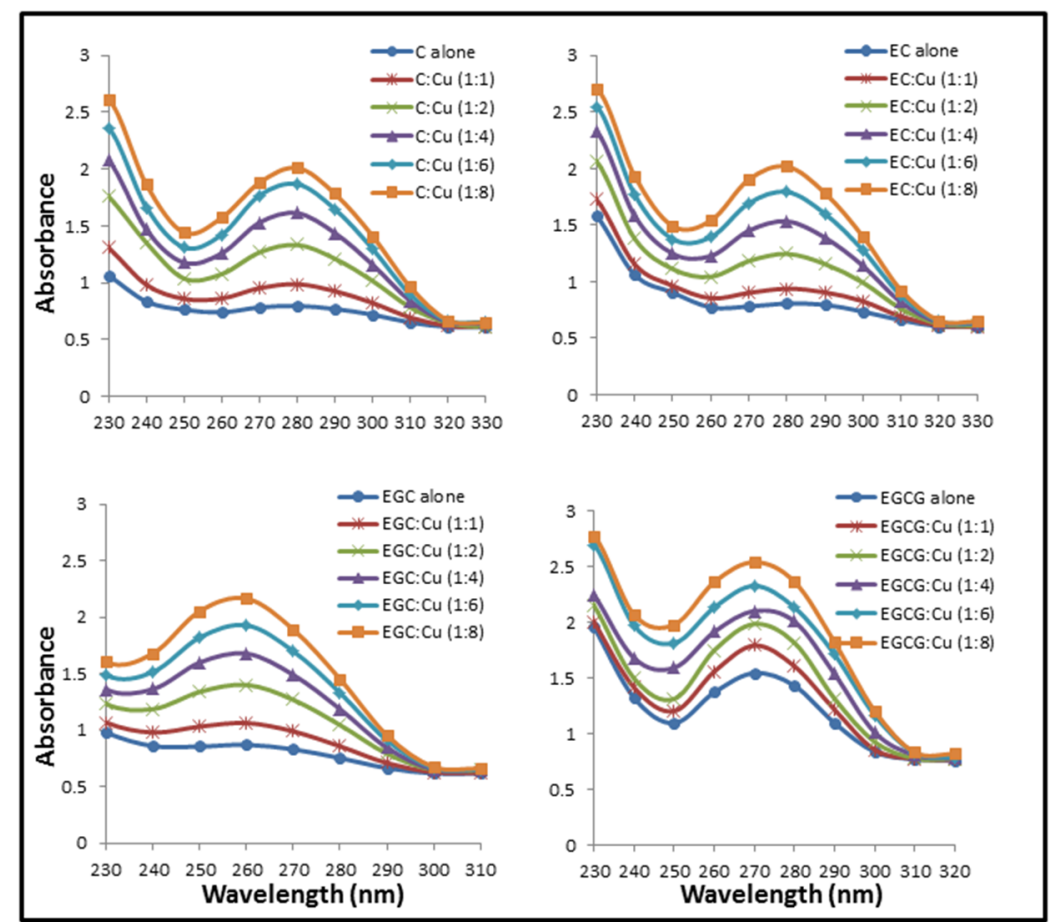

Figure 2. Effect of increasing copper concentrations on the absorbance spectra of Catechin (C), Epicatechin (EC), Epigallocatechin (EGC) and Epigallocatechin-3-gallate (EGCG). Catechins (in $10 \mathrm{mM}$ Tris- $\mathrm{HCl}, \mathrm{pH} 7.5)$ absorption spectra were recorded in the presence of increasing concentration of $\mathrm{Cu}(\mathrm{II})$.

\subsection{Formation of Complexes Involving $\mathrm{Cu}(\mathrm{II})$ with Catechins}

Figure 3 shows the effect of addition of increasing molar base pair ratios of $\mathrm{Cu}$ (II) on the fluorescence emission spectra of C, EC, EGC and EGCG excited at $273 \mathrm{~nm}$ (approximate absorption maximum of catechins). The result shown in Figure 3 indicates binding as addition of $\mathrm{Cu}(\mathrm{II})$ causes quenching of C, EC, EGC and EGCG fluorescence. These results support the result of absorption studies shown in Figure 2 where formation of catechins-copper complex was demonstrated.

\subsection{Detection of Catechins Induced Cu(I) Production by Bathocuproine}

The production of $\mathrm{Cu}(\mathrm{I})$, formed as a result of reduction of $\mathrm{Cu}(\mathrm{II})$ by $\mathrm{C}, \mathrm{EC}, \mathrm{EGC}$ and EGCG, was analyzed using bathocuproine which is a selective $\mathrm{Cu}(\mathrm{I})$ sequestering agent that binds specifically to the reduced form of copper, i.e., $\mathrm{Cu}(\mathrm{I})$, but not to the oxidized form [27]. The $\mathrm{Cu}(\mathrm{I})$-chelates exhibit an absorption maximum at $480 \mathrm{~nm}$. As shown in Figure 4, Cu(II) does not interfere with the maxima, whereas $\mathrm{C}+\mathrm{Cu}(\mathrm{II}), \mathrm{EC}+\mathrm{Cu}(\mathrm{II}), \mathrm{EGC}+\mathrm{Cu}(\mathrm{II})$ and $\mathrm{EGCG}+\mathrm{Cu}(\mathrm{II})$ react to generate $\mathrm{Cu}(\mathrm{I})$ which complexes with bathocuproine to give a peak appearing at $480 \mathrm{~nm}$. The results show that these catechins are able to reduce $\mathrm{Cu}(\mathrm{II})$ to $\mathrm{Cu}(\mathrm{I})$ and contribute to the redox cycling of the metal. 


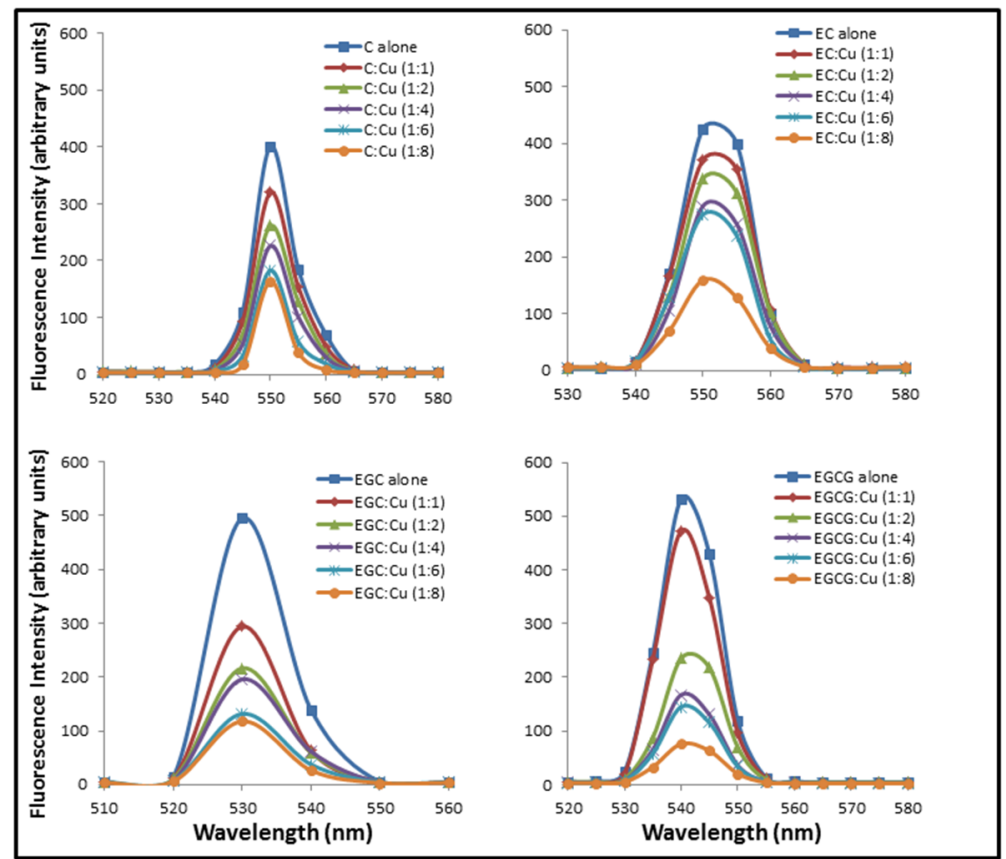

Figure 3. Effect of increasing copper concentrations on the fluorescence emission spectra of $C$, EC, EGC and EGCG. Catechins (in $10 \mathrm{mM}$ Tris-HCl, pH 7.5) were excited at $273 \mathrm{~nm}$ in the presence of increasing concentration of $\mathrm{Cu}(\mathrm{II})$ and the emission spectra were recorded between 510 and $580 \mathrm{~nm}$.

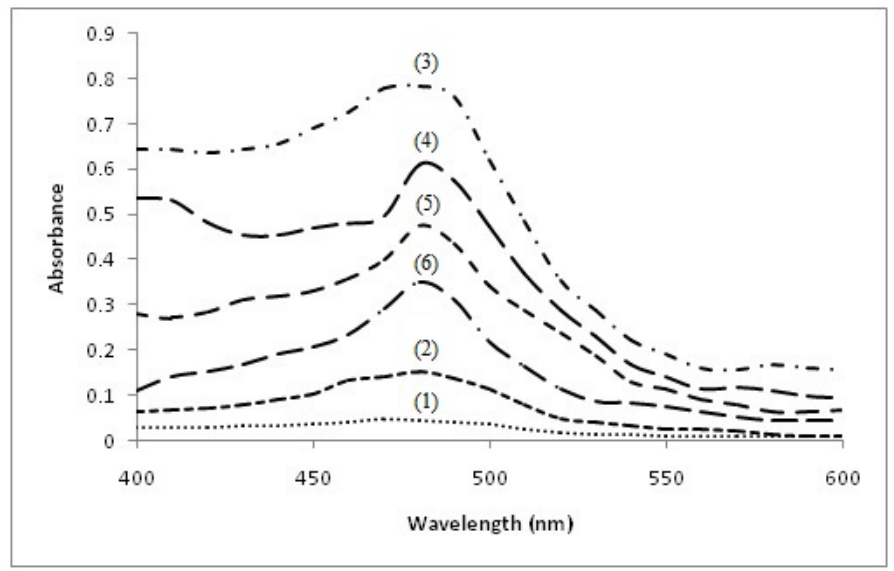

Figure 4. Detection of catechin induced $\mathrm{Cu}(\mathrm{I})$ production by Bathocuproine. Reaction mixture $(3.0 \mathrm{~mL})$ contained 3.0 mMTris- $\mathrm{HCl}(\mathrm{pH} 7.5)$ along with $300 \mu \mathrm{M}$ bathocuproine and indicated concentrations of the following: (1) Bathocuproine + $100 \mu \mathrm{M} \mathrm{Cu}$ (II); (2) Bathocuproine + $100 \mu \mathrm{M} \mathrm{Cu}$ (I); (3) Bathocuproine + $50 \mu \mathrm{M} \mathrm{C}+100 \mu \mathrm{M} \mathrm{Cu}(\mathrm{II})$; (4) Bathocuproine + $50 \mu \mathrm{M} \mathrm{EC} \mathrm{+} 100 \mu \mathrm{M} \mathrm{Cu}$ (II); (5) Bathocuproine $+50 \mu \mathrm{M} \mathrm{EGC} \mathrm{+} 100 \mu \mathrm{M} \mathrm{Cu}(\mathrm{II})$; and (6) Bathocuproine + $50 \mu \mathrm{M}$ EGCG + $100 \mu \mathrm{M} \mathrm{Cu}(\mathrm{II})$. The Bathocuproine alone or Bathocuproine in the presence of respective compounds did not interfere with the Bathocuproine- $\mathrm{Cu}(\mathrm{I})$ complex peak at $480 \mathrm{~nm}$ (not shown).

\subsection{Superoxide Production by Catechins}

The production of superoxide anion was determined by the Nakayama method [28], which involves reduction of NBT by C, EC, EGC and EGCG to a formazan. The time dependent generation of superoxide anion by C, EC, EGC and EGCG as evidenced by the increase in absorbance at $560 \mathrm{~nm}$ is shown in Figure 5. The fact that NBT was genuinely assaying superoxide was confirmed by SOD $(100 \mu \mathrm{g} / \mathrm{mL})$ inhibiting the reaction (results not shown). It is known that superoxide may undergo 
automatic dismutation to form $\mathrm{H}_{2} \mathrm{O}_{2}$ which in the presence of transition metals such as copper favors Fenton type reaction to generate hydroxyl radicals which could act as a proximal DNA cleaving agent leading to oxidative DNA breakage.

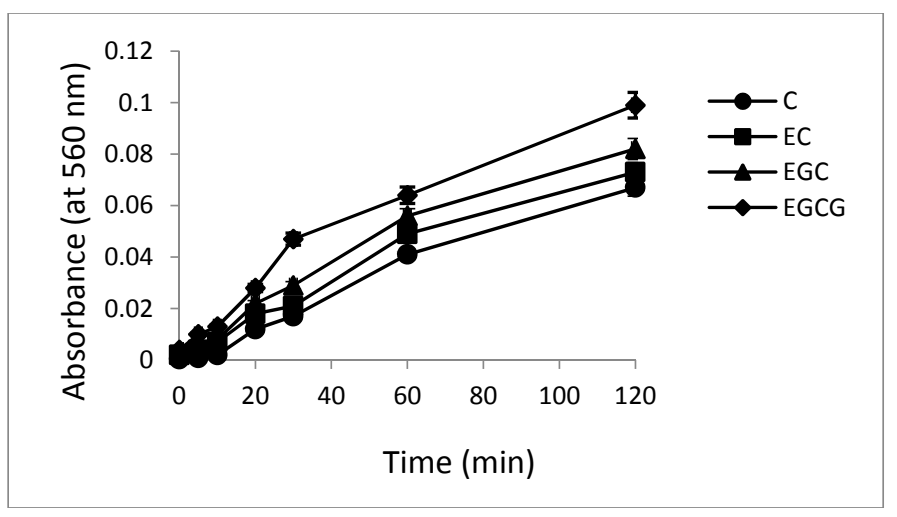

Figure 5. Photogeneration of superoxide anion by catechins on illumination under fluorescent light. Reaction mixture contained $50 \mathrm{mM}$ phosphate buffer ( $\mathrm{pH} 7.5)$ and $50 \mu \mathrm{M}$ of C, EC, EGC and EGCG. The samples were placed at a distance of $10 \mathrm{~cm}$ from the light source. All values reported are means of three independent experiments. Error bars represent standard error of mean.

\subsection{Hydroxyl Radical Generation by Catechins}

It has been previously shown that during the reduction of $\mathrm{Cu}(\mathrm{II})$ to $\mathrm{Cu}(\mathrm{I})$, reactive oxygen species such as hydroxyl radicals are formed which serve as the proximal DNA cleaving agent [29]. Therefore, the capacity of C, EC, EGC and EGCG to generate hydroxyl radical in the presence of Cu(II) was examined. The assay is based on the fact that degradation of DNA by hydroxyl radicals results in the release of TBA (2-thiobarbituric acid) reactive material, which forms a colored adduct with TBA whose absorbance is read at $532 \mathrm{~nm}$ [30]. The results given in Figure 6 clearly show that increasing concentrations of catechins lead to a progressive increase in the formation of hydroxyl radicals.

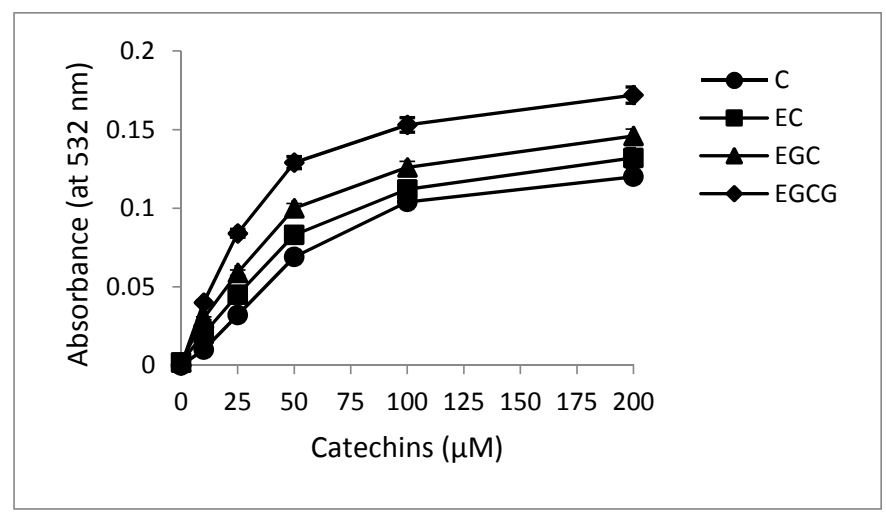

Figure 6. Formation of hydroxyl radicals as a function of catechins concentration in the presence of $\mathrm{Cu}(\mathrm{II})$. Reaction mixture $(0.5 \mathrm{~mL})$ contained $200 \mu \mathrm{g}$ calf thymus DNA as substrate, $100 \mu \mathrm{M} \mathrm{Cu}(\mathrm{II})$ and indicated concentrations of C, EC, EGC and EGCG. The reaction mixture was incubated at $37^{\circ} \mathrm{C}$ for $1 \mathrm{~h}$. Hydroxyl radical formation was measured by determining the TBA reactive material. All values reported are means of three independent experiments. Error bars represent standard error of mean.

\subsection{Breakage of Calf Thymus DNA by Catechins in the Presence of $C u$ (II)}

C, EC, EGC and EGCG in the presence of $\mathrm{Cu}(\mathrm{II})$ were found to generate single strand specific nuclease sensitive sites in calf thymus DNA. The reaction was assessed by recording the proportion 
of DNA converted to acid soluble-nucleotides by the nuclease. Table 1 gives the dose response data of such a reaction. However, C, EC, EGC and EGCG in the absence of $\mathrm{Cu}$ (II) did not show appreciable degradation of calf thymus DNA. Control experiments (data not shown) established that heat denatured DNA underwent 100\% hydrolysis following the treatment with nuclease. In the presence of $\mathrm{Cu}(\mathrm{II})(50 \mu \mathrm{M})$, increasing concentrations of C, EC, EGC and EGCG resulted in an increase in nuclease sensitive sites in DNA leading to increased DNA hydrolysis.

Table 1. Degradation of calf thymus DNA by the catechins in the presence of $\mathrm{Cu}(\mathrm{II})$ as measured by the degree of single strand specific $S_{1}$-nucleasedigestion. Reaction mixture $(0.5 \mathrm{~mL})$ containing $10 \mathrm{mM}$ Tris- $\mathrm{HCl}\left(\mathrm{pH} 7.5\right.$ ) and $500 \mu \mathrm{g}$ calf thymus DNA was incubated at $37^{\circ} \mathrm{C}$ with indicated concentrations of respective polyphenol alone or polyphenol with $\mathrm{Cu}(\mathrm{II})(100 \mu \mathrm{M})$. All values represent mean \pm SEM of three independent experiments.

\begin{tabular}{cccc}
\hline \multirow{2}{*}{ Catechins } & \multirow{2}{*}{ Concentration $(\mu \mathbf{M})$} & \multicolumn{2}{c}{ \% DNA Hydrolyzed } \\
\cline { 2 - 4 } & 50 & $1.53 \pm 0.21$ & $8.87 \pm 0.46$ \\
& 100 & $3.09 \pm 0.37$ & $11.93 \pm 0.62$ \\
$\mathrm{C}$ & 200 & $5.98 \pm 0.26$ & $17.65 \pm 0.73$ \\
& 300 & $7.11 \pm 0.67$ & $26.34 \pm 0.91$ \\
& 50 & $2.62 \pm 0.29$ & $10.43 \pm 0.41$ \\
EC & 100 & $4.18 \pm 0.35$ & $15.07 \pm 0.48$ \\
& 200 & $7.26 \pm 0.32$ & $22.32 \pm 0.81$ \\
& 300 & $9.12 \pm 0.56$ & $28.56 \pm 0.98$ \\
EGC & 50 & $3.03 \pm 0.43$ & $12.71 \pm 0.51$ \\
& 100 & $5.21 \pm 0.72$ & $16.27 \pm 0.81$ \\
& 200 & $8.11 \pm 0.54$ & $22.45 \pm 0.94$ \\
& 300 & $10.87 \pm 0.76$ & $31.17 \pm 1.13$ \\
EGCG & 50 & $4.26 \pm 0.43$ & $14.11 \pm 0.52$ \\
& 100 & $8.67 \pm 0.59$ & $18.19 \pm 0.77$ \\
& 200 & $11.89 \pm 0.74$ & $29.58 \pm 0.83$ \\
& 300 & $14.35 \pm 0.93$ & $38.74 \pm 1.71$ \\
\hline
\end{tabular}

\subsection{Cleavage of Plasmid pBR322 DNA by Catechins}

In order to examine the efficacy of catechins-Cu(II) system in DNA cleavage, as shown in Figure 7, we have tested the ability of C, EC, EGC and EGCG to cause cleavage of supercoiled plasmid pBR322 DNA in the presence of copper ions. As can be seen from the ethidium bromide stained agarose gel pattern, C, EC, EGC and EGCG alone show only some degree of DNA cleavage. However, addition of copper to these four catechins resulted in greater DNA cleavage, demonstrating that catechins are capable of plasmid DNA cleavage in the presence of copper ions.

\subsection{Cellular DNA Breakage by catechins-Cu(II) in Lymphocytes as Measured by Comet Assay}

We have earlier shown that most of the dietary polyphenolic phytochemicals, which are generally effective antioxidants, can switch to prooxidant action in the presence of transition metals such as copper $[17,18]$. In the experiment shown in Figure 8, we have tested the ability of C, EC, EGC and EGCG to cause DNA strand breaks in a cellular system of human peripheral lymphocytes both in the absence and the presence of $\mathrm{Cu}(\mathrm{II})$, as measured by standard comet assay. As seen from the figure, although all the compounds tested caused some breakage of cellular DNA, the degree of such breakage is enhanced in the presence of copper. $\mathrm{Cu}(\mathrm{II})(50 \mu \mathrm{M})$ controls were similar to untreated lymphocytes without any significant DNA breakage. The results clearly indicate that catechins-Cu(II) system is capable of DNA breakage in isolated lymphocytes and that such cellular DNA breakage is found of the order of EGCG $>$ EGC $>$ EC $>$ C. 


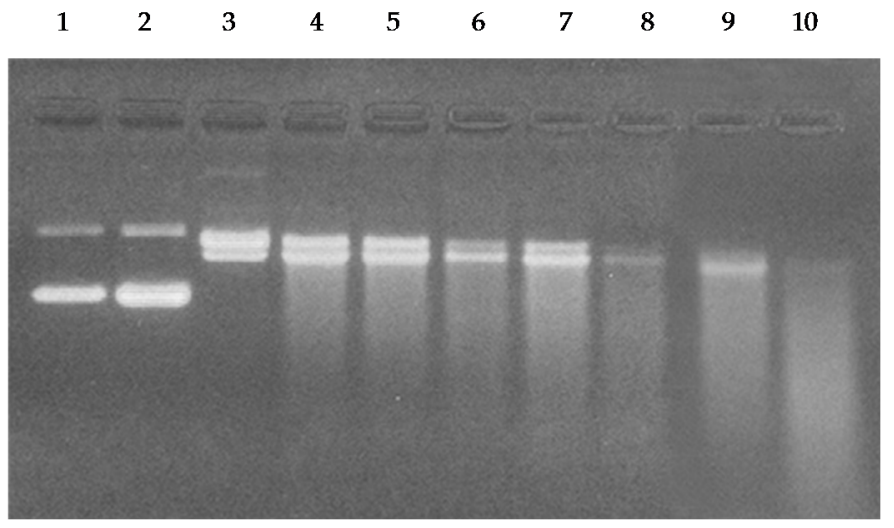

Figure 7. Agarose gel electrophoretic pattern of ethidium bromide stained pBR322 plasmid DNA after treatment with C, EC, EGC and EGCG in the absence and presence of copper. Lane 1: DNA alone; Lane 2: DNA + Cu(II) $(50 \mu \mathrm{M}) ;$ Lane 3: DNA + C (50 $\mu \mathrm{M}) ;$ Lane 4: DNA + C (50 $\mu \mathrm{M})+\mathrm{Cu}(\mathrm{II})(50 \mu \mathrm{M})$; Lane 5: DNA + EC (50 $\mu \mathrm{M})$; Lane 6: DNA + EC $(50 \mu \mathrm{M})+\mathrm{Cu}(\mathrm{II})(50 \mu \mathrm{M})$; Lane 7: DNA + EGC (50 $\mu \mathrm{M})$; Lane 8: DNA + EGC $(50 \mu \mathrm{M})+\mathrm{Cu}(\mathrm{II})(50 \mu \mathrm{M}) ;$ Lane 9: DNA + EGCG $(50 \mu \mathrm{M}) ;$ Lane 10: DNA + EGCG $(50 \mu \mathrm{M})+\mathrm{Cu}(\mathrm{II})(50 \mu \mathrm{M})$.

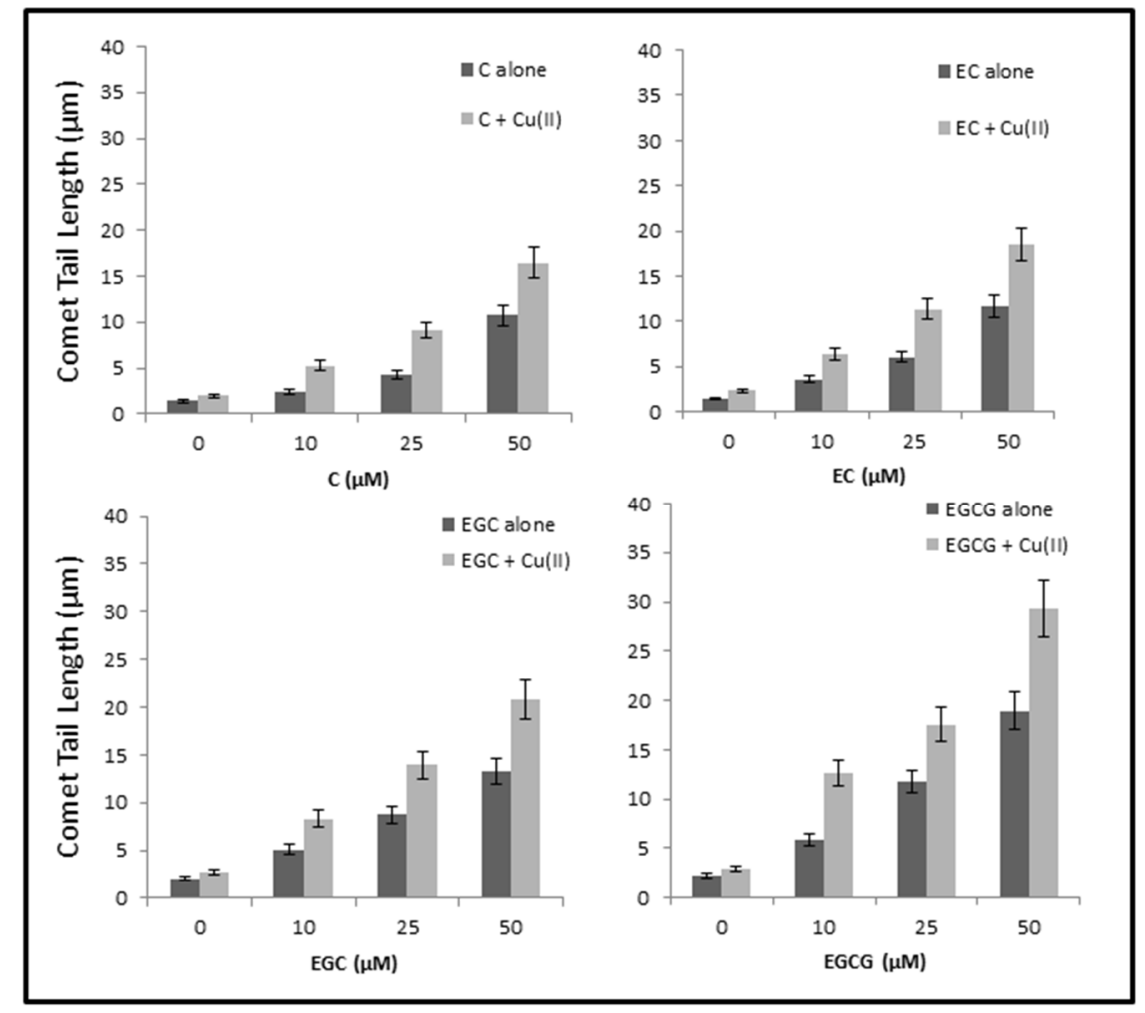

Figure 8. DNA breakage by catechins in human peripheral lymphocytes in the absence and presence of $\mathrm{Cu}(\mathrm{II})$. Comet tail length $(\mu \mathrm{ms})$ plotted as a function of increasing concentrations of catechins $(0-50 \mu \mathrm{M})$ in the absence and presence of $50 \mu \mathrm{M} \mathrm{Cu}(\mathrm{II})$. All points represent mean of three independent experiments. Error bars denote Mean \pm SEM. $p$ value $<0.05$ and significant when compared to control.

2.9. Determination of TBARS as a Measure of Oxidative Stress in Nuclei by Catechins in the Presence of Neocuproine and Thiourea

According to our hypothesis, the DNA breakage observed in lymphocyte nuclei is the result of the generation of hydroxyl radicals and other reactive oxygen species in situ. Oxygen radical 
damage to deoxyribose or DNA is considered to give rise to TBA reactive material [30,31]. We have therefore determined the formation of TBA reactive substance (TBARS) as a measure of oxidative stress in lymphocyte nuclei with increasing concentrations of C, EC, EGC and EGCG. The effect of pre-incubating the nuclei with neocuproine and thiourea was also studied. Results given in Figure 9 show a dose-dependent increase in the formation of TBA reactive substance in lymphocyte nuclei by C, EC, EGC and EGCG. However, a considerable decrease in the rate of formation of TBARS was observed in the presence of neocuproine and thiourea among all the four catechins used. The results indicate that DNA breakage in nuclei is inhibited by $\mathrm{Cu}(\mathrm{I})$ chelation and scavenging of reactive oxygen. Thus, it may be concluded that the oxidative stress induced by polyphenols in lymphocyte nuclei is at least in part mediated by chromatin bound copper.

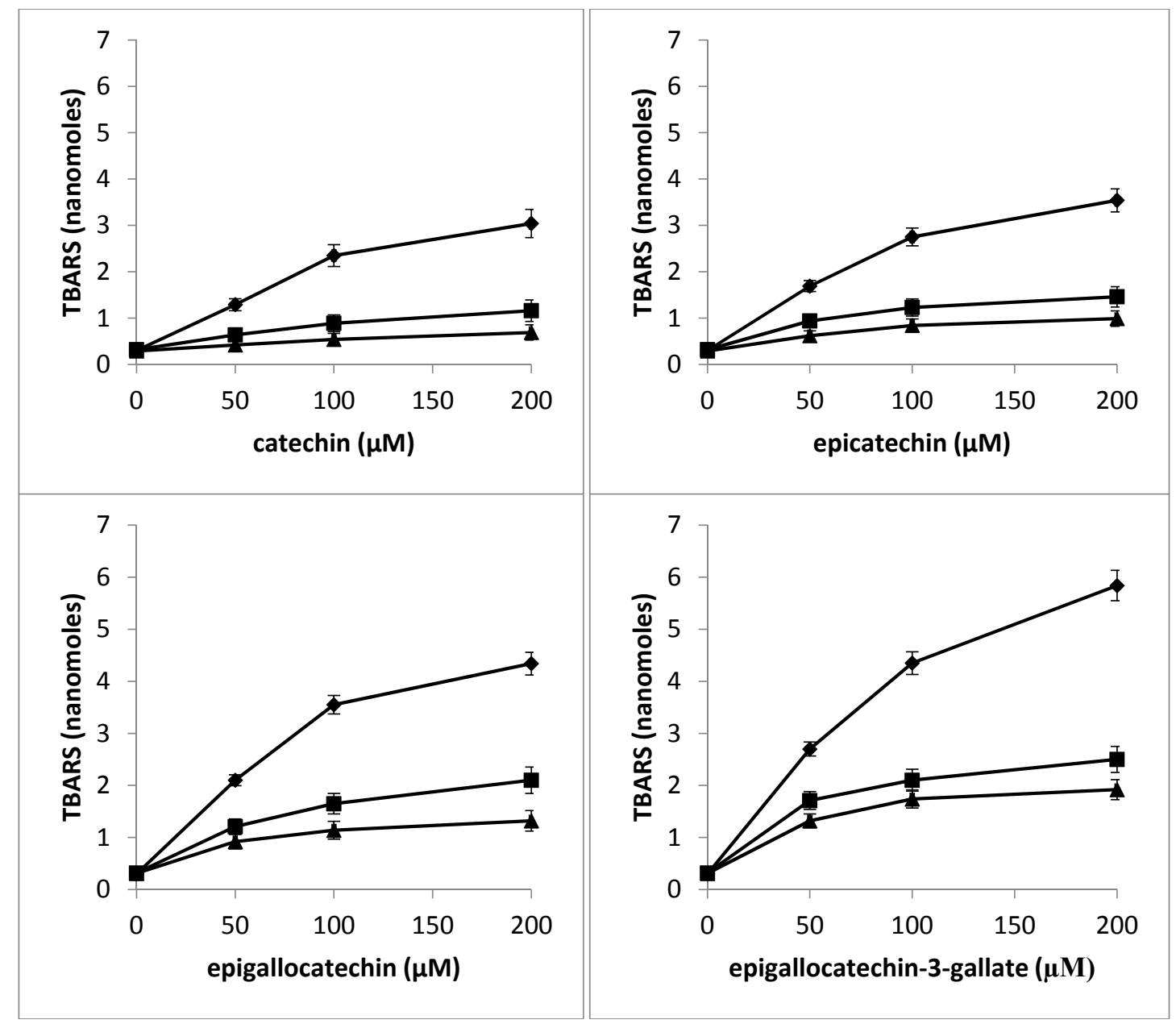

Figure 9. Effect of pre-incubation of lymphocyte nuclei with neocuproine and thiourea on TBARS generated by increasing concentrations of catechins: Catechin alone (filled circle), Catechin + neocuproine $(1 \mathrm{mM})$ (filled square), and Catechin+thiourea $(1 \mathrm{mM})$ (filled triangle). The nuclei suspension was pre-incubated with fixed concentration of neocuproine and thiourea for $30 \mathrm{~min}$ at $37^{\circ} \mathrm{C}$, after which it was further incubated for $1 \mathrm{~h}$ in the presence of increasing catechins concentration. Values reported are Mean \pm SEM of three independent experiments.

\subsection{Antioxidant Activity of Catechins against TBHP-Induced Oxidative Stress in Lymphocytes}

TBHP is a well-known inducer of ROS-mediated oxidative stress that results in DNA damage [32,33]. In the present study, we have evaluated the antioxidant potential of C, EC, EGC and EGCG in providing protection to lymphocytes against TBHP induced oxidative injury. Figure 10 shows that whereas all the four catechins were able to inhibit the TBHP-induced lymphocyte DNA 
degradation, their relative antioxidant activities were different and appeared in the following order: EGCG > EGC > EC >C. The results indicate that EGCG is the most effective antioxidant among the four catechins used.

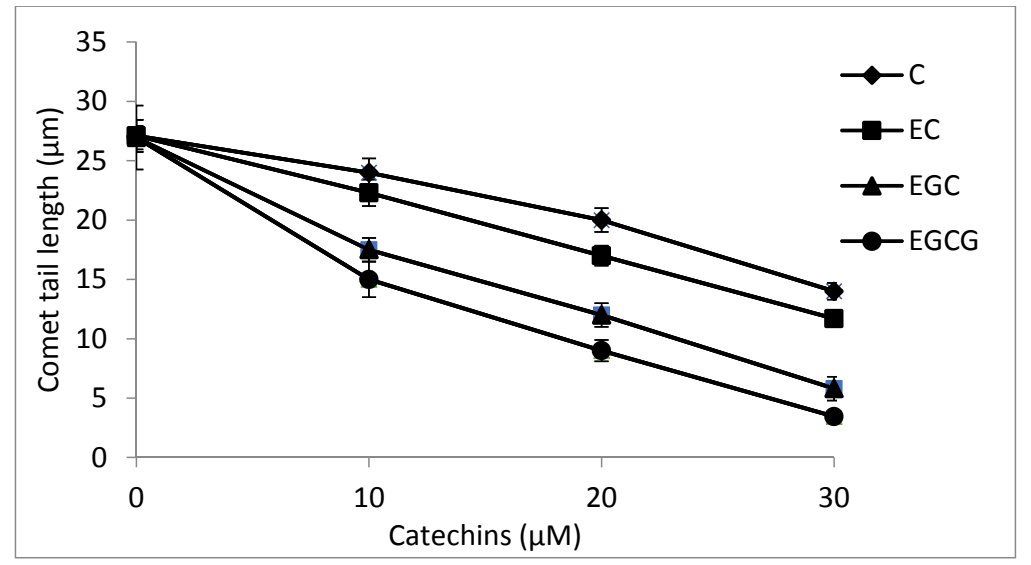

Figure 10. A comparison of antioxidant activities of various catechins as a function of decreasing tail length of comets against TBHP-induced oxidative DNA breakage in human peripheral lymphocytes as assessed by Comet assay. $p<0.05$ by comparison with TBHP-treated positive control. Values reported are Mean \pm SEM of three independent experiments.

\subsection{Catechins Cause Inhibition of Cell Growth in MDA-MB-231 Breast Cancer Cells}

In Figure 8, it was observed that catechins were able to cause strand breaks in cellular DNA. Subsequently, the effects of the various catechins were tested on the proliferative potential of human breast cancer MDA-MB-231 cells. As can be seen in Figure 11A, a dose-dependent inhibition of proliferation of breast cancer cells MDA-MB-231 by catechins was observed, as assessed by MTT assay. The order of activity was found to be EGCG $>$ EGC $>$ EC $>C$. These results complement the cellular DNA breakage studies. Further, we observed (Figure 11B) that the normal breast epithelial cells, MCF-10A, were quite resistant to EGCG treatment but their culture in copper-enriched medium resulted in sensitization to EGCG action $(p<0.01)$. These results are in agreement with our earlier published results [5] involving plant polyphenols.

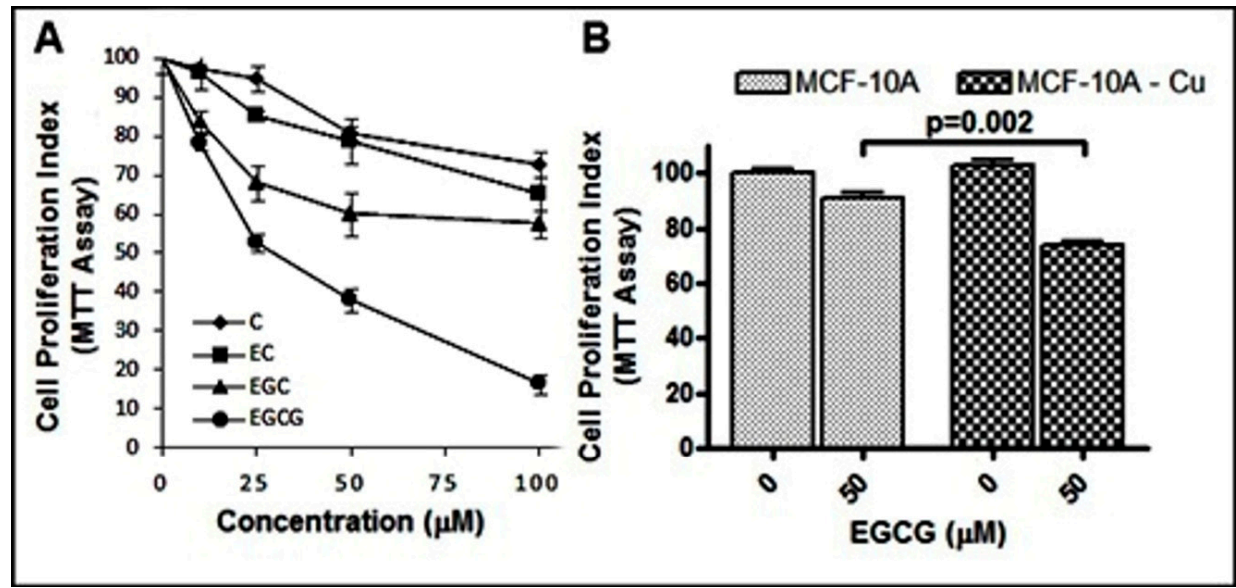

Figure 11. (A) The effects of C, EC, EGC and EGCG on the growth of MDA-MB-231 breast cancer cells as detected by MTT assay. The cells were incubated with indicated concentrations of catechins for $48 \mathrm{~h}$, and the results are expressed relative to control (vehicle-treated) cells. (B) MCF10A (normal breast epithelial cells) and MCF10A+Cu (MCF-10A cells cultured in copper-enriched medium) were treated with either vehicle $(0 \mu \mathrm{M})$ or $50 \mu \mathrm{M}$ EGCG for $72 \mathrm{~h}$. 


\section{Discussion}

Studies mainly on anticancer mechanisms of plant polyphenols involve the induction of cell cycle arrest and modulation of transcription factors that lead to anti-neoplastic effects [10,34]. In light of the above findings in our laboratory and those of many others in the literature, it may be concluded that the plant polyphenols, particularly present in dietary agents, possessing anticancer and apoptosis-inducing activities are able to mobilize endogenous copper ions, possibly the copper bound to chromatin. Essentially, this would be an alternative, non-enzymatic, and copper-dependent pathway for the cytotoxic action of anticancer agents that are capable of mobilizing and reducing endogenous copper. As such, this would be independent of Fas and mitochondria mediated programmed cell deaths. It is conceivable that such a mechanism may also lead to internucleosomal DNA breakage (a hallmark of apoptosis), as internucleosomal spacer DNA would be relatively more susceptible to cleavage by ROS. Indeed, such a common mechanism better explains the anticancer effects of dietary molecules (i.e., catechins) studied above with diverse chemical structures as also their preferential cytotoxicity toward cancer cells. The generation of hydroxyl radicals in the proximity of DNA is well established as a cause of strand scission. It is generally recognized that such a reaction with DNA is preceded by the association of a ligand with DNA followed by the formation of hydroxyl radicals at that site. The location of the redox-active metal is of utmost importance because the hydroxyl radical, owing to its extreme reactivity, interacts exclusively in the vicinity of the bound metal [35]. Copper ions are known to interact with both DNA phosphates and the bases through coordination binding [36]. Further, copper is also present in chromatin and is closely associated with DNA bases, particularly guanine [20]. Direct interaction of catechins with the DNA bound copper ions in a ternary complex and localized generation of non-diffusible hydroxyl radicals is a likely mechanism involved in catechin/ $\mathrm{Cu}(\mathrm{II})$-induced DNA cleavage. It has already been reported by us that the number of galloyl moieties present in catechinsplay an important role in cellular DNA breakage and catechins on reducing copper lead to the formation of "oxidized species" of the compounds. [26]. It may be presumed that the concentration of metals such as copper in cells is a decisive factor in driving antioxidant property of catechins toward their prooxidant action. As already mentioned, cancer cells are known to contain elevated levels of copper [37] and therefore may be more subject to electron transfer with catechins to generate ROS [25,26]. In normal cells, there exists a balance between the free radical generation and the antioxidant defense [38]. However, it has been clearly documented that tumor cells are under persistent oxidative stress and have an altered antioxidant system [39] and thus further ROS stress in malignant cells reaching a threshold level could result in apoptosis [37]. These observations further suggest that neoplastic cells may be more vulnerable to oxidative stress because they function with a heightened basal level of ROS because of increased rate of growth and metabolism [40]. Thus, in cancer cells, an enhanced exposure to ROS generated through the antioxidant/catechin-induced redox activity of endogenous copper can overwhelm the cells antioxidant capacity, leading to irreversible damage and apoptosis.

Beyond the preclinical findings, catechins such as EGCG show little promise as potent chemopreventive agents in the clinical settings, mainly owing to their inefficient systemic delivery and poor bioavailability. Catechins, like other polyphenols, are rapidly metabolized in vivo, resulting in a short systemic half-life and low plasma concentrations in the free form. For instance, it has been observed that the peak plasma concentrations reached up to $1.3 \mu \mathrm{M}$ and $3.1 \mu \mathrm{M}$ in healthy volunteers receiving $687.5 \mathrm{mg}$ EGCG and $663.5 \mathrm{mg}$ of ECG, respectively [41]. In this context, it needs to be emphasized that the significance of our work lies not so much in the potential therapeutic action of catechins against cancer, but in establishing a principle, namely that it is possible to mobilize elevated levels of endogenous copper in cancer cells by catechins to promote a pro-oxidant cell death. Once such a principle is established, catechins can serve as lead compounds to synthesize/formulate novel, anticancer drugs with superior bioavailability and extended systemic half-life. Presumably, such anticancer drugs would have a better therapeutic impact than the catechins per se.

Nevertheless, a previous study from our lab has shown that oral administration of copper to rats can induce a copper overload in their lymphocytes, rendering such isolated lymphocytes more 
susceptible to EGCG-induced pro-oxidant cellular DNA breakage [42]. This suggests that in cancer cells, where there are considerably higher levels of copper, the concentration of catechins required to elicit such a pro-oxidant cell death mechanism would be significantly lower. Therefore, based on these observations, it is clear that the pro-oxidant action of polyphenols is physiologically feasible provided an appropriate microenvironment with elevated copper levels is present, as is the scenario in cancer cells.

Further, it should be noted that in real life situation, catechins like EGCG are only one of the several polyphenols consumed as part of the diet. Since various other polyphenols present in diet, such as flavonoids and tannins are also active as pro-oxidants [17], their cumulative plasma concentration, bioavailability and anticancer effect should be much greater than a single polyphenol alone. In fact, a combination of EGCG with luteolin, has been found to be more effective than either of the polyphenol alone in inducing apoptosis in cancer cell lines in vitro and inhibition of tumor growth in nude mouse xenograft model [43].

\section{Materials and Methods}

\subsection{Chemicals, Reagents and Cell Lines}

(+)-Catechin, (-)-epicatechin, (-)-epigallocatechin, (-)-epigallocatechin-3-gallate, calf thymus DNA, cupric chloride, neocuproine, thiourea, agarose, low melting point agarose, RPMI 1640, Triton X-100, Trypan blue, Histopaque1077, and phosphate buffered saline (PBS) $\mathrm{Ca}^{2+}$ and $\mathrm{Mg}^{2+}$ free were purchased from Sigma (St. Louis, MO, USA). All other chemicals were of analytical grade. Fresh solutions of C, EC, EGC and EGCG were prepared as a stock of $3.0 \mathrm{mM}$ in double distilled water $\left(\mathrm{ddH}_{2} \mathrm{O}\right)$ before use as a stock of $1 \mathrm{mM}$ solution. Upon addition to reaction mixtures, in the presence of buffers mentioned and at concentrations used, all the catechins used remained in solution. The volumes of stock solution added did not lead to any appreciable change in the $\mathrm{pH}$ of reaction mixtures. Breast cancer cell line MDA-MB-231 was maintained in DMEM (Invitrogen, Carlsbad, CA, USA) growth media. The medium was supplemented with 10\% foetal bovine serum (FBS) and 1\% antimycotic antibiotic (Invitrogen, Carlsbad, CA, USA). Normal breast epithelial cells MCF10A were cultured in DMEM/F12 (Invitrogen, Carlsbad, CA, USA) supplemented with 5\% horse serum, $20 \mathrm{ng} / \mathrm{mL} \mathrm{EGF,}$ $0.5 \mu \mathrm{g} / \mathrm{mL}$ hydrocortisone, $0.1 \mu \mathrm{g} / \mathrm{mL}$ cholera toxin, $10 \mu \mathrm{g} / \mathrm{mL}$ insulin, 100 units $/ \mathrm{mL}$ penicillin and $100 \mu \mathrm{g} / \mathrm{mL}$ streptomycin. Cells were cultured in a $5 \% \mathrm{CO}_{2}$-humidified atmosphere at $37^{\circ} \mathrm{C}$. $\mathrm{MCF} 10 \mathrm{~A}+\mathrm{Cu}$ cells are MCF10A cells cultured with additional supplementation of $25 \mu \mathrm{M} \mathrm{CuCl}_{2}$ for at least 4 weeks. A $5 \mathrm{mg} / \mathrm{mL}$ stock solution of 3-(4,5-dimethylthiazol-2-yl)-2,5-diphenyltetrazolium bromide (MTT) was prepared in PBS.

\subsection{Absorbance Studies}

The effect of increasing concentrations of $\mathrm{Cu}(\mathrm{II})$ on absorption spectra of $\mathrm{C}, \mathrm{EC}, \mathrm{EGC}$ and EGCG was observed. The reaction mixture $(3.0 \mathrm{~mL})$ contained $10 \mathrm{mMTris}-\mathrm{HCl}(\mathrm{pH} 7.5), 50 \mu \mathrm{M} \mathrm{C}, \mathrm{EC}, \mathrm{EGC}$, EGCG and increasing concentrations of $\mathrm{Cu}(\mathrm{II})$. The spectra were recorded immediately after addition of all components.

\subsection{Flourescence Studies}

The fluorescence studies were performed on a Shimadzu spectrofluorometer RF-5310 PC (Kyoto, Japan) equipped with a plotter and a calculator. C, EC, EGC and EGCG were excited at their absorption maxima $\left(\lambda_{\max }\right)$ of $273 \mathrm{~nm}$ (approximate absorption maximum of catechins). Emission spectra were recorded in the wavelength range shown in figures.

\subsection{Detection of $\mathrm{Cu}(\mathrm{II})$ Reduction}

The selective sequestering agent bathocuproine was employed to detect reduction of $\mathrm{Cu}(\mathrm{II})$ to $\mathrm{Cu}(\mathrm{I})$ by recording the formation of bathocuproine- $\mathrm{Cu}(\mathrm{I})$ complex which absorbs maximally at 
$480 \mathrm{~nm}$. The reaction mixture $(3.0 \mathrm{~mL})$ contained $3.0 \mathrm{mM}$ Tris- $\mathrm{HCl}(\mathrm{pH} 7.5)$, fixed concentrations $(100 \mu \mathrm{M})$ of $\mathrm{Cu}(\mathrm{II})$ and $\mathrm{Cu}(\mathrm{I})$ (for positive control), bathocuproine (300 $\mu \mathrm{M})$ and of catechins (C, EC, EGC and EGCG) $(50 \mu \mathrm{M})$. The reaction was started by adding $\mathrm{Cu}(\mathrm{II})$ and the spectra were recorded immediately afterwards.

\subsection{Detection of Superoxide Anion Generation}

Superoxide $\left(\mathrm{O}_{2}{ }^{-}\right)$was detected by the reduction of nitroblue tetrazolium (NBT) essentially as described by Nakayama et al. [28]. A typical assay mixture contained $50 \mathrm{mM}$ sodium phosphate buffer (pH 7.5), $33 \mu \mathrm{M}$ NBT, $100 \mu \mathrm{M}$ EDTA and $0.06 \%$ triton $\mathrm{X}-100$ in a total volume of $3.0 \mathrm{~mL}$. The reaction was started by the addition of catechins (C/EC/EGC/EGCG). After mixing, absorbance was recorded at $560 \mathrm{~nm}$ at different time intervals, against a blank, which did not contain the compound.

\subsection{Detection of Hydroxyl Radical Generation}

In order to compare the hydroxyl radical production by increasing concentrations of C, EC, EGC and EGCG in the presence of $100 \mu \mathrm{M} \mathrm{Cu}(\mathrm{II})$, the method of Quinlan and Gutteridge [30] was followed. Calf thymus DNA $(200 \mu \mathrm{g})$ was used as a substrate and the malondialdehyde generated from deoxyribose radicals was assayed by recording the absorbance at $532 \mathrm{~nm}$.

\subsection{Degradation of Calf Thymus DNA}

Single strand specific digestion was performed as described by Wani and Hadi [44]. Reaction mixtures $(0.5 \mathrm{~mL})$ contained $10 \mathrm{mM}$ Tris- $\mathrm{HCl}(\mathrm{pH} 7.5), 500 \mu \mathrm{g}$ of calf thymus DNA and varying amounts of C, EC, EGC, EGCG and cupric chloride $(50 \mu \mathrm{M})$. All solutions were sterilized before use. Incubation was performed at $37^{\circ} \mathrm{C}$ for one hour. The assay determines the acid soluble nucleotides released from DNA as a result of enzyme digestion. Reaction mixture in a total volume of $1.0 \mathrm{~mL}$ contained $40 \mathrm{mM}$ Tris- $\mathrm{HCl}$ (pH 7.5), $1 \mathrm{mM}$ Magnesium Chloride, water and enzyme. The reaction mixture was incubated at $37{ }^{\circ} \mathrm{C}$ for $2 \mathrm{~h}$. The reaction was stopped by adding $0.2 \mathrm{~mL}$ bovine serum albumin $(10 \mathrm{mg} / \mathrm{mL})$ and $1.0 \mathrm{~mL}$ of $14 \%$ perchloric acid (chilled). The tubes were immediately transferred to $0{ }^{\circ} \mathrm{C}$ for $45 \mathrm{~min}$ before centrifugation at $2500 \mathrm{rpm}$ for $10 \mathrm{~min}$ at room temperature to remove undigested DNA and precipitated protein. Acid soluble deoxyribonucleotides were determined in the supernatant, colorimetrically, using the diphenylamine method [45]. To a $1.0 \mathrm{~mL}$ aliquot, $2.0 \mathrm{~mL}$ diphenyl reagent (freshly prepared by dissolving 1 gram of recrystallized diphenylamine in $100 \mathrm{~mL}$ glacial acetic acid and $2.75 \mathrm{~mL}$ of concentrated $\mathrm{H}_{2} \mathrm{SO}_{4}$ ) was added. The tubes were heated in a boiling water bath for $30 \mathrm{~min}$. The intensity of blue color was read at $600 \mathrm{~nm}$.

\subsection{Treatment of $p B R 322 D N A$}

Reaction mixture $(30 \mu \mathrm{L})$ contained $10 \mathrm{mMTris}-\mathrm{HCl}(\mathrm{pH} 7.5), 0.5 \mu \mathrm{g}$ of plasmid DNA and other components as indicated in legends. Incubation was performed at $37^{\circ} \mathrm{C}$ for $2 \mathrm{~h}$. After incubation, $10 \mu \mathrm{L}$ of solution containing $40 \mathrm{mM}$ EDTA, 0.05\% bromophenol blue (tracking dye) and 50\% $(v / v)$ glycerol was added and the solution was subjected to electrophoresis in submarine $1 \%$ agarose gel. The gel was stained with ethidium bromide $(0.5 \mu \mathrm{g} / \mathrm{mL})$, viewed and photographed on a UV-transilluminator.

\subsection{Isolation of Lymphocytes}

Heparinized blood samples $(2 \mathrm{~mL})$ from a single, healthy, non-smoking donor was obtained by venepuncture and diluted suitably in $\mathrm{Ca}^{2+}$ and $\mathrm{Mg}^{2+}$ free PBS. Lymphocytes were isolated from blood using Histopaque 1077 (Sigma Diagnostics, St Louis, MS, USA), and the cells were finally suspended in RPMI 1640. 


\subsection{Viability Assessment of Lymphocytes}

The lymphocytes were checked for their viability before the start and after the end of the reaction using Trypan Blue Exclusion Test by Pool-Zobel et al. [46]. The viability of the cells was found to be greater than $93 \%$.

\subsection{Comet Assay}

Comet assay was performed under alkaline conditions essentially according to the procedure of Singh et al. [47] with slight modifications. Fully frosted microscopic slides precoated with $1.0 \%$ normal melting agarose at about $50{ }^{\circ} \mathrm{C}$ (dissolved in $\mathrm{Ca}^{2+}$ and $\mathrm{Mg}^{2+}$ free PBS) were used. Approximately 10,000 cells were mixed with $75 \mu \mathrm{L}$ of $2.0 \%$ LMPA to form a cell suspension and pipetted over the first layer and covered immediately by a coverslip. The agarose layer was allowed to solidify by placing the slides on a flat tray and keeping it on ice for $10 \mathrm{~min}$. The coverslips were removed and a third layer of $0.5 \%$ LMPA $(75 \mu \mathrm{L})$ was pipetted and coverslips placed over it and kept on ice for $5 \mathrm{~min}$ for proper solidification of layer. The coverslips were removed and the slides were immersed in cold lysing solution containing $2.5 \mathrm{M} \mathrm{NaCl}, 100 \mathrm{mM}$ EDTA, $10 \mathrm{mM}$ Tris, $\mathrm{pH}$ 10, and 1\% Triton $\mathrm{X}-100$ added just prior to use for a minimum of $1 \mathrm{~h}$ at $4{ }^{\circ} \mathrm{C}$. After lysis DNA was allowed to unwind for $30 \mathrm{~min}$ in alkaline electrophoretic solution consisting of $300 \mathrm{mM} \mathrm{NaOH}, 1 \mathrm{mM}$ EDTA, pH > 13 . Electrophoresis was performed at $4{ }^{\circ} \mathrm{C}$ in a field strength of $0.7 \mathrm{~V} / \mathrm{cm}$ and $300 \mathrm{~mA}$ current. The slides were then neutralized with cold $0.4 \mathrm{M}$ Tris, pH 7.5, stained with $75 \mu \mathrm{L}$ Ethidium Bromide $(20 \mu \mathrm{g} / \mathrm{mL})$ and covered with a coverslip. The slides were placed in a humidified chamber to prevent drying of the gel and analyzed the same day. Slides were scored using an image analysis system (Komet 5.5, Kinetic Imaging, Liverpool, UK) attached to a Olympus (CX41) fluorescent microscope and a COHU 4910 (equipped with a 510-560 nm excitation and $590 \mathrm{~nm}$ barrier filters) integrated CC camera. Comets were scored at $100 \times$ magnification. Images from 50 cells ( 25 from each replicate slide) were analyzed. The parameter taken to assess lymphocytes DNA damage was tail length (migration of DNA from the nucleus, $\mu \mathrm{m}$ ) and was automatically generated by Komet 5.5 image analysis system.

Treatment of intact lymphocytes with four catechins (C, EC, EGC and EGCG) and the subsequent Comet assay was performed essentially as described earlier by Azmi et al. [48]. For antioxidant study [49], the cells were preincubated with polyphenols in eppendorf tubes in a reaction volume of $1.0 \mathrm{~mL}$. After the preincubation (for $30 \mathrm{~min}$ at $37^{\circ} \mathrm{C}$ ), the reaction mixture was centrifuged at $4000 \mathrm{rpm}$, the supernatant was discarded and the pelleted lymphocytes were resuspended in $100 \mu \mathrm{L}$ of PBS $\left(\mathrm{Ca}^{2+}\right.$ and $\mathrm{Mg}^{2+}$ free) and layered for further treatment with TBHP $(50 \mu \mathrm{M})$. The incubation period was $30 \mathrm{~min}$ at $37^{\circ} \mathrm{C}$ in dark. The other conditions remained the same as described above.

\subsection{Determination of TBARS}

Thiobarbituric acid reactive substance was determined according to the method of Ramanathan et al. [50]. A cell suspension $\left(1 \times 10^{5} / \mathrm{mL}\right)$ was incubated with C, EC, EGC and EGCG $(0-200 \mu \mathrm{M})$ at $37^{\circ} \mathrm{C}$ for $1 \mathrm{~h}$ and then centrifuged at $1000 \mathrm{rpm}$. In some experiments the cells were pre-incubated with fixed concentrations of neocuproine and thiourea. The cell pellet was washed twice with phosphate buffered saline $\left(\mathrm{Ca}^{2+}\right.$ and $\mathrm{Mg}^{2+}$ free) and suspended in $0.1 \mathrm{~N} \mathrm{NaOH}$. This cell suspension $(1.4 \mathrm{~mL})$ was further treated with $10 \%$ TCA and $0.6 \mathrm{M}$ TBA (2-thiobarbituric acid) in boiling water bath for $10 \mathrm{~min}$. The absorbance was read at $532 \mathrm{~nm}$ and converted into nmoles of TBA reactive substance using the molar extinction coefficient $\left(1.56 \times 9 \times 105 \mathrm{M}^{-1} \cdot \mathrm{cm}^{-1}\right)$.

\subsection{Cell Growth Inhibition Studies by MTT Assay}

MDA-MB-231 cells were seeded at a density of $1 \times 10^{4}$ cells per well in 96-well microtiter culture plates. After overnight incubation, normal growth medium was removed and replaced with either fresh medium (untreated control) or different concentrations of respective catechins in growth medium. After the desired time of incubation $(48 \mathrm{~h})$, MTT solution was added to each well $(0.1 \mathrm{mg} / \mathrm{mL}$ in 
DMEM) and incubated further for 4 hours at $37^{\circ} \mathrm{C}$. Upon termination, the supernatant was aspirated and the MTT formazan, formed by metabolically viable cells, was dissolved in a solubilisation solution containing DMSO $(100 \mu \mathrm{L})$ by mixing for 5 min on a gyratory shaker. The absorbance was measured at $540 \mathrm{~nm}$ (reference wavelength $690 \mathrm{~nm}$ ) on an Ultra Multifunctional Microplate Reader (Bio-Rad, Hercules, CA, USA). Absorbance of control (without treatment) was considered as $100 \%$ cell survival. Each treatment had four replicate wells and the mean values were plotted.

\subsection{Statistics}

The statistical analysis was performed as described by Tice et al. [51] and is expressed as mean \pm SEM/SD of three independent experiments. A student's $t$-test was used for examining statistically significant differences. Analysis of variance was performed using ANOVA. $p$ values $<0.05$ were considered statistically significant.

Acknowledgments: Authors are thankful to BSR, UGC, New Delhi, for providing financial assistance for the research work. We are also thankful to the Department of Biochemistry, AMU, Aligarh for providing us the necessary facilities.

Author Contributions: MF, HYK, MO, AAH, NR and HA performed experiments. MF analyzed data and drafted manuscript. AA helped in the manuscript draft. SMH conceptualized the study, provided facilities and oversaw the project.

Conflicts of Interest: The authors declare no conflict of interest.

\section{References}

1. Adlercreutz, C.H.; Goldin, B.R.; Gorbach, S.L.; Hockerstedt, K.A.; Watanabe, S.; Hamalainen, E.K.; Markkanen, M.H.; Makela, T.H.; Wahala, K.T.; Adlercreutz, T. Soybean phytoestrogen intake and cancer risk. J. Nutr. 1995, 125, 757S-770S. [PubMed]

2. Park, O.J.; Surh, Y.J. Chemopreventive potential of epigallocatechin gallate and genistein: Evidence from epidemiological and laboratory studies. Toxicol. Lett. 2004, 150, 43-56. [CrossRef] [PubMed]

3. Barnes, S.; Peterson, G.; Grubbs, C.; Setchell, K. Potential role of dietary isoflavones in the prevention of cancer. Adv. Exp. Med. Biol. 1994, 354, 135-147. [PubMed]

4. Surh, Y.J. Cancer chemoprevention with dietary phytochemicals. Nat. Rev. Cancer 2003, 3, 768-780. [CrossRef] [PubMed]

5. Khan, H.Y.; Zubair, H.; Faisal, M.; Ullah, M.F.; Farhan, M.; Sarkar, F.H.; Ahmad, A.; Hadi, S.M. Plant polyphenol induced cell death in human cancer cells involves mobilization of intracellular copper ions and reactive oxygen species generation: A mechanism for cancer chemopreventive action. Mol. Nutr. Food Res. 2014, 58, 437-446. [CrossRef] [PubMed]

6. Yang, G.Y.; Liao, J.; Kim, K.; Yurkow, E.J.; Yang, C.S. Inhibition of growth and induction of apoptosis in human cancer cell lines by tea polyphenols. Carcinogenesis 1998, 19, 611-616. [CrossRef] [PubMed]

7. Shamim, U.; Hanif, S.; Ullah, M.F.; Azmi, A.S.; Bhat, S.H.; Hadi, S.M. Plant polyphenols mobilize nuclear copper in human peripheral lymphocytes leading to oxidatively generated DNA breakage: Implications for an anticancer mechanism. Free Radic. Res. 2008, 42, 764-772. [CrossRef] [PubMed]

8. Ullah, M.F.; Ahmad, A.; Khan, H.Y.; Zubair, H.; Sarkar, F.H.; Hadi, S.M. The prooxidant action of dietary antioxidants leading to cellular DNA breakage and anticancer effects: Implications for chemotherapeutic action against cancer. Cell Biochem. Biophys. 2013, 67, 431-438. [CrossRef] [PubMed]

9. Clement, M.V.; Hirpara, J.L.; Chawdhury, S.H.; Pervaiz, S. Chemopreventive agent resveratrol, a natural product derived from grapes, triggers cd95 signaling-dependent apoptosis in human tumor cells. Blood 1998, 92, 996-1002. [PubMed]

10. Kuo, M.L.; Huang, T.S.; Lin, J.K. Curcumin, an antioxidant and anti-tumor promoter, induces apoptosis in human leukemia cells. Biochim. Biophys. Acta 1996, 1317, 95-100. [CrossRef]

11. Chang, K.L.; Cheng, H.L.; Huang, L.W.; Hsieh, B.S.; Hu, Y.C.; Chih, T.T.; Shyu, H.W.; Su, S.J. Combined effects of terazosin and genistein on a metastatic, hormone-independent human prostate cancer cell line. Cancer Lett. 2009, 276, 14-20. [CrossRef] [PubMed] 
12. Gupta, S.; Hastak, K.; Ahmad, N.; Lewin, J.S.; Mukhtar, H. Inhibition of prostate carcinogenesis in tramp mice by oral infusion of green tea polyphenols. Proc. Natl. Acad. Sci. USA 2001, 98, 10350-10355. [CrossRef] [PubMed]

13. Orsolic, N.; Knezevic, A.; Sver, L.; Terzic, S.; Hackenberger, B.K.; Basic, I. Influence of honey bee products on transplantable murine tumours. Vet. Comp. Oncol. 2003, 1, 216-226. [CrossRef] [PubMed]

14. Chen, Z.P.; Schell, J.B.; Ho, C.T.; Chen, K.Y. Green tea epigallocatechin gallate shows a pronounced growth inhibitory effect on cancerous cells but not on their normal counterparts. Cancer Lett. 1998, 129, 173-179. [CrossRef]

15. Said Ahmad, M.; Fazal, F.; Rahman, A.; Hadi, S.M.; Parish, J.H. Activities of flavonoids for the cleavage of DNA in the presence of cu(ii): Correlation with generation of active oxygen species. Carcinogenesis 1992, 13, 605-608. [CrossRef] [PubMed]

16. Gali, H.U.; Perchellet, E.M.; Klish, D.S.; Johnson, J.M.; Perchellet, J.P. Hydrolyzable tannins: Potent inhibitors of hydroperoxide production and tumor promotion in mouse skin treated with 12-o-tetradecanoylphorbol-13-acetate in vivo. Int. J. Cancer 1992, 51, 425-432. [CrossRef] [PubMed]

17. Hadi, S.M.; Asad, S.F.; Singh, S.; Ahmad, A. Putative mechanism for anticancer and apoptosis-inducing properties of plant-derived polyphenolic compounds. IUBMB Life 2000, 50, 167-171. [PubMed]

18. Hadi, S.M.; Bhat, S.H.; Azmi, A.S.; Hanif, S.; Shamim, U.; Ullah, M.F. Oxidative breakage of cellular DNA by plant polyphenols: A putative mechanism for anticancer properties. Semin. Cancer Biol. 2007, 17, 370-376. [CrossRef] [PubMed]

19. Bhat, S.H.; Azmi, A.S.; Hanif, S.; Hadi, S.M. Ascorbic acid mobilizes endogenous copper in human peripheral lymphocytes leading to oxidative DNA breakage: A putative mechanism for anticancer properties. Int. J. Biochem. Cell Biol. 2006, 38, 2074-2081. [CrossRef] [PubMed]

20. Kagawa, T.F.; Geierstanger, B.H.; Wang, A.H.; Ho, P.S. Covalent modification of guanine bases in double-stranded DNA. The 1.2-A Z-DNA structure of d(CGCGCG) in the presence of $\mathrm{CuCl}_{2}$. J. Biol. Chem. 1991, 266, 20175-20184. [PubMed]

21. Ebadi, M.; Swanson, S. The status of zinc, copper, and metallothionein in cancer patients. Prog. Clin. Biol. Res. 1988, 259, 161-175. [PubMed]

22. Margalioth, E.J.; Udassin, R.; Cohen, C.; Maor, J.; Anteby, S.O.; Schenker, J.G. Serum copper level in gynecologic malignancies. Am. J. Obstet. Gynecol. 1987, 157, 93-96. [CrossRef]

23. Yoshida, D.; Ikeda, Y.; Nakazawa, S. Quantitative analysis of copper, zinc and copper/zinc ratio in selected human brain tumors. J. Neuro-Oncol. 1993, 16, 109-115. [CrossRef]

24. Ebara, M.; Fukuda, H.; Hatano, R.; Saisho, H.; Nagato, Y.; Suzuki, K.; Nakajima, K.; Yukawa, M.; Kondo, F.; Nakayama, A.; et al. Relationship between copper, zinc and metallothionein in hepatocellular carcinoma and its surrounding liver parenchyma. J. Hepatol. 2000, 33, 415-422. [CrossRef]

25. Zheng, L.F.; Wei, Q.Y.; Cai, Y.J.; Fang, J.G.; Zhou, B.; Yang, L.; Liu, Z.L. DNA damage induced by resveratrol and its synthetic analogues in the presence of $\mathrm{Cu}$ (II) ions: Mechanism and structure-activity relationship. Free Radic. Biol. Med. 2006, 41, 1807-1816. [CrossRef] [PubMed]

26. Farhan, M.; Zafar, A.; Chibber, S.; Khan, H.Y.; Arif, H.; Hadi, S.M. Mobilization of copper ions in human peripheral lymphocytes by catechins leading to oxidative DNA breakage: A structure activity study. Arch. Biochem. Biophys. 2015, 580, 31-40. [CrossRef] [PubMed]

27. Simpson, J.A.; Narita, S.; Gieseg, S.; Gebicki, S.; Gebicki, J.M.; Dean, R.T. Long-lived reactive species on free-radical-damaged proteins. Biochem. J. 1992, 282, 621-624. [CrossRef] [PubMed]

28. Nakayama, T.; Kimura, T.; Kodama, M.; Nagata, C. Generation of hydrogen peroxide and superoxide anion from active metabolites of naphthylamines and aminoazo dyes: Its possible role in carcinogenesis. Carcinogenesis 1983, 4, 765-769. [CrossRef] [PubMed]

29. Rahman, A.; Shahabuddin; Hadi, S.M.; Parish, J.H.; Ainley, K. Strand scission in DNA induced by quercetin and $\mathrm{Cu}(\mathrm{II})$ : Role of $\mathrm{Cu}(\mathrm{I})$ and oxygen free radicals. Carcinogenesis 1989, 10, 1833-1839. [CrossRef] [PubMed]

30. Quinlan, G.J.; Gutteridge, J.M. Oxygen radical damage to DNA by rifamycin sv and copper ions. Biochem. Pharmacol. 1987, 36, 3629-3633. [CrossRef]

31. Smith, C.; Halliwell, B.; Aruoma, O.I. Protection by albumin against the pro-oxidant actions of phenolic dietary components. Food Chem. Toxicol. 1992, 30, 483-489. [CrossRef] 
32. Dubuisson, M.L.; de Wergifosse, B.; Trouet, A.; Baguet, F.; Marchand-Brynaert, J.; Rees, J.F. Antioxidative properties of natural coelenterazine and synthetic methyl coelenterazine in rat hepatocytes subjected to tert-butyl hydroperoxide-induced oxidative stress. Biochem. Pharmacol. 2000, 60, 471-478. [CrossRef]

33. Suzuki, Y.; Apostolova, M.D.; Cherian, M.G. Astrocyte cultures from transgenic mice to study the role of metallothionein in cytotoxicity of tert-butyl hydroperoxide. Toxicology 2000, 145, 51-62. [CrossRef]

34. Ahmad, N.; Feyes, D.K.; Nieminen, A.L.; Agarwal, R.; Mukhtar, H. Green tea constituent epigallocatechin-3-gallate and induction of apoptosis and cell cycle arrest in human carcinoma cells. J. Natl. Cancer Inst. 1997, 89, 1881-1886. [CrossRef] [PubMed]

35. Chevion, M. A site-specific mechanism for free radical induced biological damage: The essential role of redox-active transition metals. Free Radic. Biol. Med. 1988, 5, 27-37. [CrossRef]

36. Zimmer, C.; Luck, G.; Fritzsche, H.; Triebel, H. DNA-copper (II) complex and the DNA conformation. Biopolymers 1971, 10, 441-463. [CrossRef] [PubMed]

37. Gupte, A.; Mumper, R.J. Elevated copper and oxidative stress in cancer cells as a target for cancer treatment. Cancer Treat. Rev. 2009, 35, 32-46. [CrossRef] [PubMed]

38. Devi, G.S.; Prasad, M.H.; Saraswathi, I.; Raghu, D.; Rao, D.N.; Reddy, P.P. Free radicals antioxidant enzymes and lipid peroxidation in different types of leukemias. Clin. Chim. Acta 2000, 293, 53-62. [CrossRef]

39. Oberley, T.D.; Oberley, L.W. Antioxidant enzyme levels in cancer. Histol. Histopathol. 1997, 12, $525-535$. [PubMed]

40. Kong, Q.; Beel, J.A.; Lillehei, K.O. A threshold concept for cancer therapy. Med. Hypotheses 2000, 55, $29-35$. [CrossRef] [PubMed]

41. Van Amelsvoort, J.M.; Van Hof, K.H.; Mathot, J.N.; Mulder, T.P.; Wiersma, A.; Tijburg, L.B. Plasma concentrations of individual tea catechins after a single oral dose in humans. Xenobiotica: Fate Foreign Compd. Biol. Syst. 2001, 31, 891-901. [CrossRef] [PubMed]

42. Khan, H.Y.; Zubair, H.; Ullah, M.F.; Ahmad, A.; Hadi, S.M. Oral administration of copper to rats leads to increased lymphocyte cellular DNA degradation by dietary polyphenols: Implications for a cancer preventive mechanism. Biometals 2011, 24, 1169-1178. [CrossRef] [PubMed]

43. Amin, A.R.; Wang, D.; Zhang, H.; Peng, S.; Shin, H.J.; Brandes, J.C.; Tighiouart, M.; Khuri, F.R.; Chen, Z.G.; Shin, D.M. Enhanced anti-tumor activity by the combination of the natural compounds (-)-epigallocatechin-3-gallate and luteolin: Potential role of p53. J. Biol. Chem. 2010, 285, 34557-34565. [CrossRef] [PubMed]

44. Wani, A.A.; Hadi, S.M. Partial purification and properties of an endonuclease from germinating pea seeds specific for single-stranded DNA. Arch. Biochem. Biophys. 1979, 196, 138-146. [CrossRef]

45. Schneider, W.C. Determination of nucleic acids in tissues by pentose analysis. Methods Enzymol 1957, 3, 880-884.

46. Pool-Zobel, B.L.; Guigas, C.; Klein, R.; Neudecker, C.; Renner, H.W.; Schmezer, P. Assessment of genotoxic effects by lindane. Food Chem. Toxicol. 1993, 31, 271-283. [CrossRef]

47. Singh, N.P.; McCoy, M.T.; Tice, R.R.; Schneider, E.L. A simple technique for quantitation of low levels of DNA damage in individual cells. Exp. Cell Res. 1988, 175, 184-191. [CrossRef]

48. Azmi, A.S.; Bhat, S.H.; Hadi, S.M. Resveratrol-Cu(II) induced DNA breakage in human peripheral lymphocytes: Implications for anticancer properties. FEBS Lett. 2005, 579, 3131-3135. [CrossRef] [PubMed]

49. Kanupriya; Dipti, P.; Sharma, S.K.; Sairam, M.; Ilavazhagan, G.; Sawhney, R.C.; Banerjee, P.K. Flavonoids protect u-937 macrophages against tert-butylhydroperoxide induced oxidative injury. Food Chem. Toxicol. 2006, 44, 1024-1030. [CrossRef] [PubMed]

50. Ramanathan, R.; Das, N.P.; Tan, C.H. Effects of gamma-linolenic acid, flavonoids, and vitamins on cytotoxicity and lipid peroxidation. Free Radic. Biol. Med. 1994, 16, 43-48. [CrossRef]

51. Tice, R.R.; Strauss, G.H. The single cell gel electrophoresis/comet assay: A potential tool for detecting radiation-induced DNA damage in humans. Stem Cells 1995, 13 (Suppl. 1), 207-214. [PubMed]

(C) 2016 by the authors; licensee MDPI, Basel, Switzerland. This article is an open access article distributed under the terms and conditions of the Creative Commons by Attribution (CC-BY) license (http:/ / creativecommons.org/licenses/by/4.0/). 